\title{
SURVIVAL AND SPROUTING RESPONSES OF CHIHUAHUA PINE AFTER THE RODEO-CHEDISKI FIRE ON THE MOGOLLON RIM, ARIZONA
}

\author{
Kenneth H. Baumgartner ${ }^{1}$ and Peter Z. Fulé1,2
}

\begin{abstract}
Aвstract.-Chihuahua pines (Pinus leiophylla Schiede and Deppe var. chihuahuana Engelmann) were surveyed on 11 study plots on the Mogollon Rim in east central Arizona to compare characteristics of trees that sprouted from the base or root collar after the Rodeo-Chediski fire with those of trees that did not sprout. The differences in trees killed and top-killed by the fire versus those that survived were also assessed. Trees that sprouted were significantly smaller in height and diameter at breast height; they also experienced lower fire intensities than trees that did not sprout. Smaller trees had higher incidences of mortality than larger trees. These results indicate that, even though Chihuahua pine has fire resiliency, sprouting rates after fire are related to size of trees, age of trees, and burn intensity. Since Chihuahua pine is a rare species in the area studied, its ability to recover from and tolerate fire could prove advantageous for sustainability.
\end{abstract}

Key words: Chihuahua pine, sprouting, vegetative reproduction, fire resilience, fire resistance, fire ecology, regeneration, pine.

Pinus leiophylla Schiede and Deppe var. chihuahuana Engelmann (Chihuahua pine) is one of the few pines that sprout in response to disturbance. This species can sprout both from its base (Stone and Stone 1954) and from the stem or crown (Farjon and Styles 1997). It is considered a fire-resilient species, having a low to moderate tolerance to fire but an ability to regenerate rapidly through the mechanism of sprouting (McCune 1988). The ability to sprout is believed to be restricted to young and juvenile trees. Of all the North American pines, $P$. leiophylla has the best ability to sprout from the base (McCune 1988). Mature trees have thick bark (Perry 1991), which may help insulate cambial tissue from fire (Pavek 1994).

In the United States, P. leiophylla grows in southwestern New Mexico and southeastern and east central Arizona on dry slopes ranging from 1524 to $2438 \mathrm{~m}$ in elevation (Petrides 1992). Pinus leiophylla is most commonly found in the mountains of southeastern Arizona; however, it is rare and sporadic on the Mogollon Rim in east central Arizona (Petrides 1992, Muldavin et al. 1996).

In east central Arizona, the Rodeo-Chediski fire burned approximately 189,000 ha in 2002 and was the largest fire recorded in Arizona
(USDA Forest Service 2002). This fire, which burned portions of the Mogollon Rim, provided the opportunity to assess post-fire sprouting characteristics of $P$. leiophylla in an area where it is rare, where it is the only pine species in the area that sprouts following fire, and where it is at its northern latitudinal limit (Petrides 1992). Considering that large crown fires are likely to continue occurring in the area (Covington et al. 1994), response of this population to fire has significant implications for sustainability of $P$. leiophylla on the Mogollon Rim.

We asked 3 questions regarding the effects of fire on basal sprouting of P. leiophylla in stands burned in the Rodeo-Chediski fire on the Mogollon Rim: (1) does tree age have an influence on the ability to resprout; (2) does fire intensity have an influence on the ability to resprout; and (3) does tree age have an influence on survival? We assessed the results of this study in the context of P. leiophylla management.

\section{METHODS}

The study was conducted on the RodeoChediski burn in the Black Mesa Ranger District of the Apache-Sitgreaves National Forest

${ }^{1}$ Ecological Restoration Institute and School of Forestry, Northern Arizona University, Box 15018, Flagstaff, AZ 86011.
${ }^{2}$ Corresponding author. E-mail: pete.fule@nau.edu 


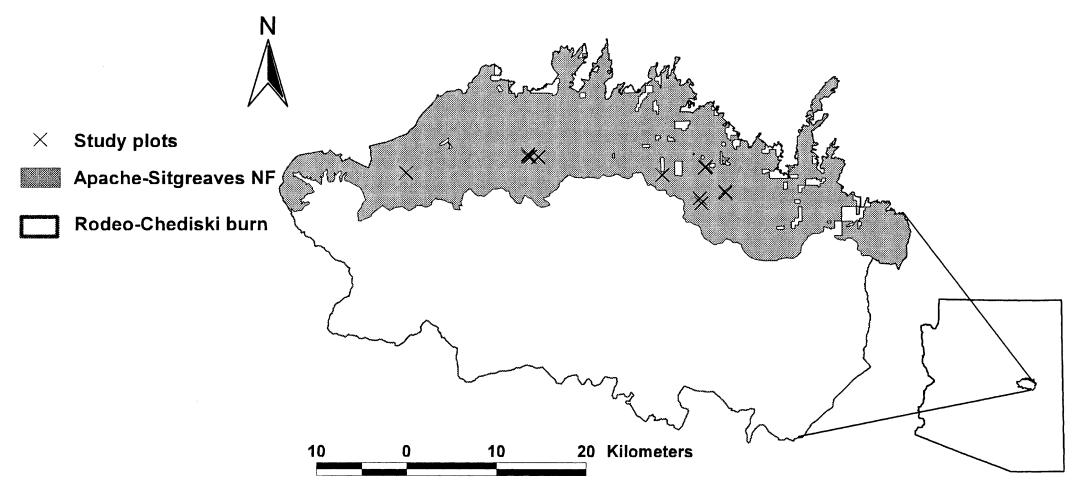

Fig. 1. Map of study area in the Black Mesa Ranger District on the Apache-Sitgreaves National Forest.

near Heber, Arizona. The area receives an average annual precipitation of around 44.3 $\mathrm{cm}$ and an average annual snowfall of $99.3 \mathrm{~cm}$. Average monthly temperatures range from $-8.9^{\circ}$ to $29.3^{\circ} \mathrm{C}$, with the minimum occurring in January and the maximum in July (Western Regional Climate Center 2004). Average elevation for all study sites was approximately 2092 m ASL (range 2027-2245 m). Soil information was derived from a Terrestrial Ecosystem Survey (Laing et al. 1987). Study sites were located on Udic and Lythic Haplustalfs (C.A. Nelson, USDA Forest Service, personal communication, 2005), with parent material derived from alluvium and sandstone. Trees and shrubs consisted of Chihuahua pine, ponderosa pine (Pinus ponderosa Laws.), white fir (Abies concolor Gord. \& Glen.), alligator juniper (Juniperus deppeana Steud.), Gambel oak (Quercus gambelii Nutt.), pointleaf manzanita (Arctostaphylos pungens Kunth), and Fendler ceanothus (Ceanothus fendleri Gray).

We selected 11 study plots based on known locations of $P$. leiophylla. Plots were located over a distance of approximately $37 \mathrm{~km}$ (Fig. 1). Due to the rarity of $P$. leiophylla in the area, it was necessary to locate plots in a subjective manner. We chose sample plots in areas where P. leiophylla was in greatest abundance and made an effort to include a variety of tree sizes and sprouting responses. Each plot was $50 \times$ $20 \mathrm{~m}$ and permanently marked with an iron stake at the northeast corner. Every P. leiophylla individual was sampled regardless of size, due to the ability of very young (small) trees to sprout. For each tree, we measured the following attributes: condition (live or dead), diameter at breast height (dbh), total height, height of live crown base, minimum and maximum char heights, whether or not the stem sprouted, and number of basal sprouts. Increment cores were taken from a subset of trees to determine ages. We assumed that the majority of charred, recently killed trees were killed by the Rodeo-Chediski fire. We also assumed char height was correlated positively with flame length and thus was an approximation of fireline intensity near the individual trees as in Agee (1993).

Within each plot, we sampled subplots for other overstory trees, shrubs, and regeneration. Other overstory tree species were identified within the northeast quadrant and diameters at breast height were measured. A $5 \times 10-\mathrm{m}$ shrub plot originating from the northeast corner was used to tally live and dead shrubs and tree regeneration. The heights of shrubs and regeneration were recorded into 3 height classes: 0-40 cm, $41-80 \mathrm{~cm}$, and $81-137 \mathrm{~cm}$.

We took photos at each plot from the northeast corner facing into the plot center. UTM coordinates were recorded at the northeast corner. Plot aspect and slope were recorded. Plots were corrected for slope in the field.

Data were analyzed with JMP (release 5.0.1.2; SAS, Inc., Cary, NC). We compared characteristics of sprouting and nonsprouting trees including diameters, total heights, and minimum and maximum char heights. Diameters of trees that survived the fire and trees that did not were also compared. Most data were found to have nonnormal distributions and unequal variances, but these problems were corrected with square-root transformations. 
TABLE 1. Average tree density of Pinus leiophylla and other tree species after the Rodeo-Chediski fire for the 11 study plots.

\begin{tabular}{|c|c|c|c|c|}
\hline Species & Density $\left(\right.$ trees $\left.\cdot \mathrm{ha}^{-1}\right)$ & $s_{\bar{x}}$ & Minimum & Maximum \\
\hline \multicolumn{5}{|l|}{ Pinus leiophylla } \\
\hline Live & 216 & 56.3 & 10 & 640 \\
\hline Dead & 225 & 48.8 & 40 & 520 \\
\hline Total & 441 & 55.7 & 170 & 720 \\
\hline Pinus ponderosa & 262 & 120.3 & 0 & 1360 \\
\hline Juniperus deppeana & 18 & 11.3 & 0 & 120 \\
\hline Quercus gambelii & 4 & 3.6 & 0 & 40 \\
\hline
\end{tabular}

TABLE 2. Average basal area (BA) of Pinus leiophylla and other tree species for the 11 study plots.

\begin{tabular}{lcccc}
\hline Species & $\mathrm{BA}\left(\mathrm{m}^{2} \cdot \mathrm{ha}^{-1}\right)$ & $s_{\bar{x}}$ & Minimum & Maximum \\
\hline Pinus leiophylla & & & & 9.7 \\
$\quad$ Live & 4.3 & 0.9 & 0 & 5.9 \\
Dead & 1.4 & 0.5 & 1.2 & 10.7 \\
Total & 5.7 & 0.8 & 0 & 16.8 \\
Pinus ponderosa & 3.0 & 1.6 & 0 & 1.6 \\
Juniperus deppeana & 0.2 & 0.1 & 0.1 \\
Quercus gambelii & $<0.1$ & 0 & 0.1 \\
\hline
\end{tabular}

A Welch ANOVA was used to test data with unequal variances.

\section{RESULTS}

Among living plants in the 11 plots sampled post-fire, $P$. leiophylla and $P$. ponderosa were codominant. Pinus ponderosa density was slightly higher than that of $P$. leiophylla, but basal area was higher for P. leiophylla. There was also a small amount of Juniperus deppeana and Quercus gambelii (Tables 1, 2), both of which were observed to be sprouting from the base in a manner similar to P. leiophylla. Arctostaphylos pungens and Ceanothus fendleri were the only shrubs we found. Arctostaphylos pungens was the dominant shrub.

We found a positive linear relationship $\left(\mathrm{R}^{2}\right.$ $=0.6324, y=4.493 x-4.2857, P<0.0001)$ between dbh and age of $P$. leiophylla. The oldest tree dated was 220 years old and the youngest was 26 years old.

Of all P. leiophylla individuals sampled, $34 \%$ sprouted from the base and $61 \%$ were topkilled in the fire. The averages on a per-plot basis were similar to the average of all trees sampled (Table 3). The highest mortality rate of P. leiophylla occurred mostly in smaller dbh classes and was generally lower in larger dbh classes. There was no mortality in the 30-35$\mathrm{cm}$ or the 35-40-cm classes (Fig. 2). Diame-
TABle 3. Summary of live and dead (top-killed) P. leiophylla with basal sprouts for the 11 study plots.

\begin{tabular}{lr}
\hline Summary statistics $(n=11$ plots $)$ & \\
\hline Total trees sampled & 441 \\
Percent with basal sprouts & 34 \\
$\quad$ Percent live & 39 \\
Percent top-killed & 61 \\
Averages & \\
Percent sprouting (trees per plot) & 37 \\
$\quad$ Percent live & 37 \\
Percent top-killed & 63 \\
\hline
\end{tabular}

ters were significantly greater for live trees than for dead and top-killed trees $(t=6.13, P$ $<0.0001$; Table 4).

Individuals of $P$. leiophylla that sprouted from the base had significantly different characteristics from those that did not sprout. Trees with basal sprouts were smaller in dbh $(F=61.42, P<0.0001)$, shorter in total height $(F=44.50, P<0.0001)$, and had lower maximum char heights $(F=6.31, P=0.0130)$ than trees that did not sprout (Table 5). The majority of trees that sprouted from the base were in the $0-5-\mathrm{cm}$ diameter class (Fig. 3) and reflected the distribution of dbh (Fig. 2). The proportion of sprouting from dead trees decreased with increasing dbh (Fig. 3). 


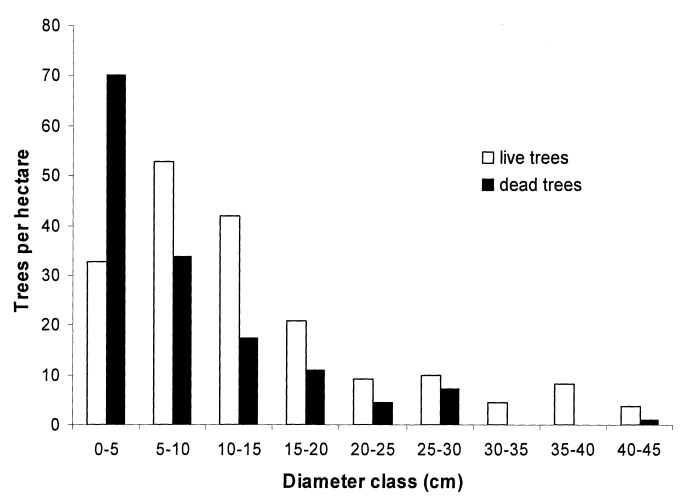

Fig. 2. Distribution of diameters at breast height of live and dead individuals of Pinus leiophylla for the 11 study plots. Dead trees were killed by the fire.

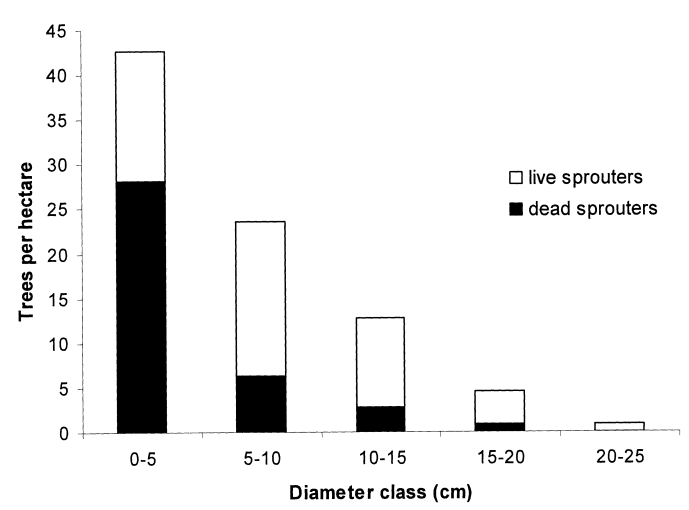

Fig. 3. Distribution of diameters at breast height of live and dead trees that sprouted from the base after the Rodeo-Chediski fire for the 11 study plots.

\section{Discussion}

Consistent with McCune (1988), P. leiophylla demonstrated an ability to resprout from the base following the Rodeo-Chediski fire (Fig. 4A, 4C). Sprouting by P. leiophylla following this fire occurred both from topkilled trees and from live trees. For top-killed trees, however, sprouting was not uniform, because higher char height on trees, indicating greater fire intensity (Agee 1993), was associated with reduced sprouting response. This suggests that, though P. leiophylla is known to be resilient to fire, this resilience may be negatively influenced by increased fire intensity.
TABLE 4. Differences in diameters of post-fire live and dead Pinus leiophylla for the 11 study plots.

\begin{tabular}{lcccc}
\hline & \multicolumn{4}{c}{ Diameter $(\mathrm{dbh} ; \mathrm{cm})$} \\
\cline { 2 - 5 } & $\bar{x}$ & $s_{\bar{x}}$ & Minimum & Maximum \\
\hline Live & 13.1 & 0.70 & 0.3 & 44.4 \\
Dead & 7.9 & 0.59 & 0.2 & 41.2 \\
\hline
\end{tabular}

This study also supports the observation of Perry (1991) that sprouting of P. leiophylla occurs mostly in young trees. This poses an important implication for management of forests containing this species. To have a favorable sprouting response to fire, stands of P. leiophylla should be managed to ensure that there are significant numbers of trees with diameters at breast height $<30 \mathrm{~cm}$.

The observations in this study indicate that P. leiophylla has certain distinct advantages compared to other tree species in the area. Since $P$. leiophylla is the only sprouting pine species on the Mogollon Rim, its ability to sprout as a form of regeneration following fire could be an important advantage over $P$. ponderosa. Because sprouting is not dependent upon a crop of seeds, P. leiophylla can regenerate even when all the trees in an area have been killed. This ability could potentially mean the difference between pines being dominant in an area after fire versus dominance of another tree or shrub species. Pinus leiophylla also possesses a degree of fire resistance in mature trees. This may serve as an advantage over other sprouting species that do not possess thick bark and are more easily top-killed, such as oaks.

That P. leiophylla has shown considerable regeneration immediately after the RodeoChediski fire has implications for tree diversity on the Mogollon Rim. Currently, P. leiophylla is a rare species in the area, but given the advantages mentioned above, it may likely increase in abundance in the future.

Though this study identified important traits related to sprouting, more extensive research should be done on this species to assess the relationships between bark thickness and tree age, size, and fire resistance; factors that cause or influence stem and basal sprouting; and ability of sprouts to produce cones. The height, growth, and survival of basal sprouts should be studied over time to assess whether postfire sprouting translates into mature trees. Also, 
TABLE 5. Differences in characteristics of sprouting and nonsprouting Pinus leiophylla for the 11 study plots.

\begin{tabular}{lcccc}
\hline & $\bar{x}$ & $s_{\bar{x}}$ & Minimum & Maximum \\
\hline Diameter (dbh; cm) & & & & \\
$\quad$ Sprouters & 5.7 & 0.46 & 0.1 & 4.8 \\
$\quad$ Nonsprouters & 11.9 & 0.58 & 0.2 & 9.8 \\
Total height (m) & & & 0.1 & 15.3 \\
$\quad$ Sprouters & 3.1 & 0.21 & 0.3 & 6.6 \\
$\quad$ Nonsprouters & 5.1 & 0.19 & & 10.8 \\
$\quad$ Maximum char height (m) & 1.25 & 0.13 & 0.1 & \\
$\quad$ Sprouters & 1.72 & 0.11 & & \\
$\quad$ Nonsprouters & & & & \\
\hline
\end{tabular}
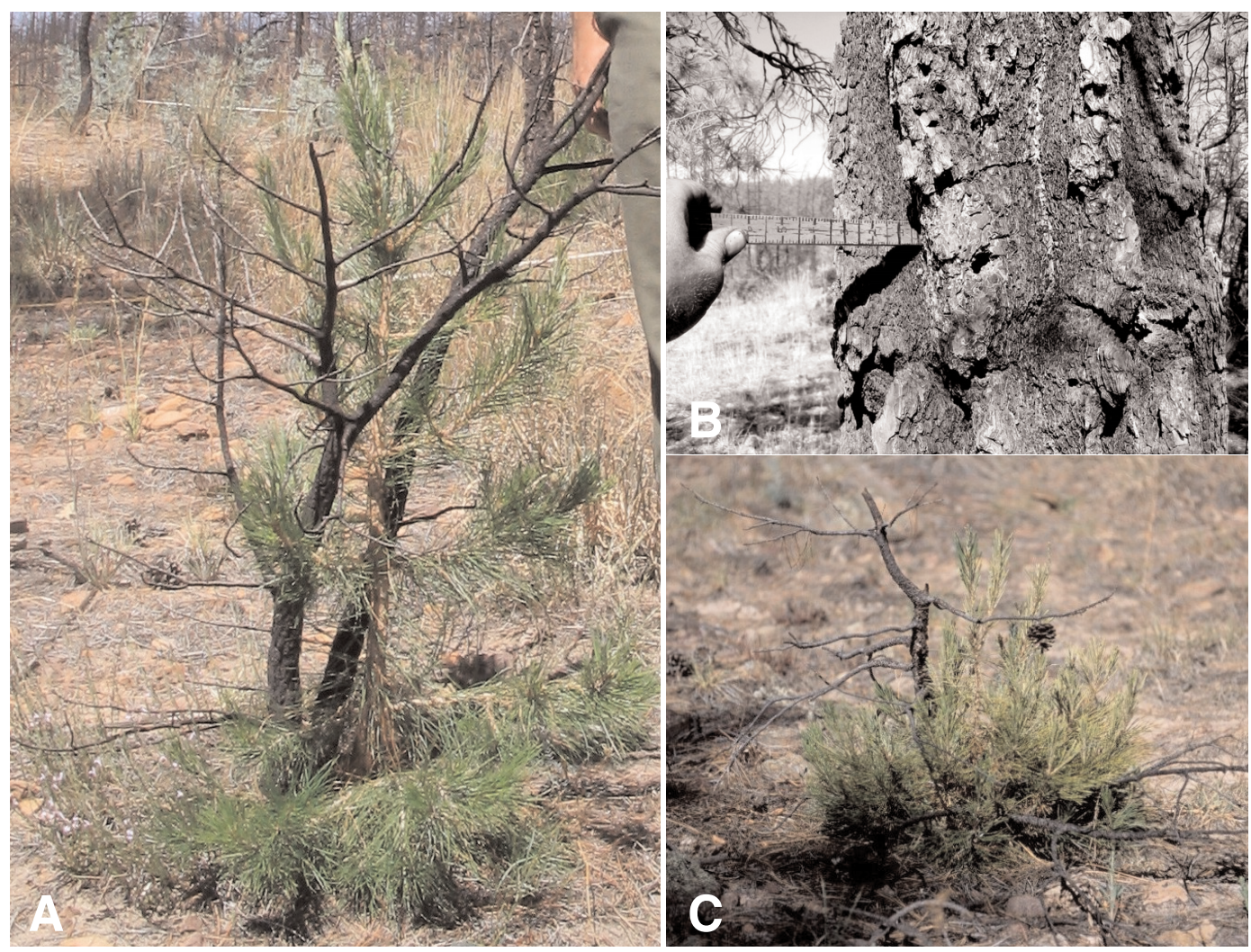

Fig. 4. (A) Single large basal sprout of Pinus leiophylla originating from a juvenile tree; (B) thick bark on mature tree; (C) small tree with multiple small basal sprouts. 
it would be interesting to compare the sprouting response to fire of $P$. leiophylla with the sprouting responses of $Q$. gambelii and J. deppeana on the Mogollon Rim to assess post-fire interactions of these species.

\section{ACKNOWLEDgments}

Many thanks go to Gayle Richardson of the Black Mesa Ranger District, Sitgreaves National Forest, for her support of the project and help in locating study sites. We thank Tom Kolb, Dave Huffman, Robin Long, Chris McGlone, Mark Daniels, Don Normandin, and Mike Stoddard for their comments. We also greatly appreciate the help of Matt Tuten, Barb Strom, Amanda Kuenzi, Stephanie Smith, Jeff Rainey, Lang Suby, and Cam Altree.

\section{Literature Cited}

Agee, J.K. 1993. Fire ecology of Pacific Northwest forests. Island Press, Washington, DC.

Covington, W.W., R.L. Everett, R. Steele, L.L. Irwin, T.A. DaER, AND A.N.D. AuClair. 1994. Historical and anticipated changes in forest ecosystems of the inland west of the United States. Journal of Sustainable Forestry 2(1-2):13-63.

Farjon, A., AND B.T. Styles. 1997. Pinus (Pinaceae). Flora Neotropica: Monograph 75. Organization for Flora Neotropica. The New York Botanical Garden, New York.
Laing, L., N. Ambos, T. Subirge, C. McDonald, C. NelSON, AND W. RobBIE. 1987. Terrestrial ecosystem survey of the Apache-Sitgreaves National Forests. U.S. Department of Agriculture, Forest Service, Southwestern Region, Albuquerque, NM.

McCune, B. 1988. Ecological diversity in North American pines. American Journal of Botany 75:353-368.

Muldavin, E.H., R.L. DeVelice, and F. Ronco, Jr. 1996. A classification of forest habitat types: southern Arizona and portions of the Colorado Plateau. USDA Forest Service General Technical Report RMGTR-287, Rocky Mountain Forest and Range Experiment Station, Fort Collins, CO.

Pavek, D.S. 1994. Pinus leiophylla var. chihuahuana. Fire Effects Information System [Online]. USDA Forest Service, Rocky Mountain Research Station, Fire Sciences Laboratory, producer. Available from: http:// www.fs.fed.us/database/feis/.

Perry, J.P., JR. 1991. The pines of Mexico and Central America. Timber Press, Portland, OR.

Petrides, G.A. 1992. A field guide to western trees: western United States and Canada. Peterson Field Guide Series. Houghton Mifflin.

Stone, E.L., JR., AND M.H. Stone. 1954. Root collar sprouts in pine. Journal of Forestry 52:487-491.

[WRCC] Western Regional Climate Center. 2004. Heber Ranger Station, Arizona: Period of record monthly climate summary. Available from: http://www. wrcc.dri.edu/cgi-bin/cliMAIN.pl?azhebe

USDA Forest SERVICE. 2002. Rodeo-Chediski fire effects summary report. Unpublished data on file with Apache-Sitgreaves National Forests, Springerville, AZ.

Received 3 March 2005 Accepted 8 August 2006 